\title{
BITING ACTIVITY OF AEDES SCAPULARIS (RONDANI) AND HAEMAGOGUS MOSQUITOES IN SOUTHERN BRAZIL (DIPTERA: CULICIDAE)*
}

Oswaldo Paulo Forattini* hi Almério de Castro Gomes**

FORATTINI, O. P. \& GOMES, A. de C. Biting activity of Aedes scapularis (Rondani) and Haemagogus mosquitoes in Southern Brazil (Diptera: Culicidae). Rev. Saúde públ., S. Paulo, 22:84-93, 1988.

ABSTRACT: The biting activity of a population of Aedes scapularis (Rondani), Haemagogus capricornii Lutz and $\boldsymbol{H g}$. leucocelaenus (Dyar and Shannon) in Southern Brazil was studied between March 1980 and April 1983. Data were obtained with 25-hour human bait catches in three areas with patchy residual forests, named "Jacaré-Pepira", "Lupo" Farm, and "Sta. Helena" Farm, in the highland region of S. Paulo State (Brazil). Data obtained on Ae. scapularis were compared with those formerly gathered in the "Ribeira" Valley lowlands, and were similar, except in the "Lupo" Farm study area, where a precrepuscular peak was observed, not recorded at the "Jacaré-Pepira" site or in the "Ribeira" Valley. In all the areas this mosquito showed diurnal and nocturnal activity, but was most active during the evening crepuscular period. These observations support the hypothesis about the successful adaptation of Ae. scapularis to man-made environments and have epidemiological implications that arise from it. As for Haemagogus, results obtained on the "Lupo" and "Sta. Helena" regions agree with previous data obtained in several other regions and show its diurnal activity. The proximity of "Lupo" Farm, where $\mathrm{Hg}$. capricornii and $\mathrm{Hg}$. leucocelaenus showed considerable activity, to "Araraquara" city where Aedes aegypti was recently found, raises some epidemiological considerations about the possibility of urban yellow fever resurgence.

UNITERMS: Aedes scapularis. Haemagogus capricornii. Haemagogus leucocelaenus. Vectors, insects. Haematophagy. Ecology vectors. Arbovirus infections, transmission.

\section{INTRODUCTION}

From the epidemiological point of view, $A e$ des scapularis is among those mosquitoes of the Neotropical region deserving attention. Being a very common and widespread species, its increasing adaptation to modified environments and to domiciliarity, have made it an important subject of research (Foratti$\mathrm{ni}^{6}, 1961$; Forattini et $\left.\mathrm{al}^{13}, 1987\right)$. Its competence and epidemiological capacity to transmit infective and parasitic agents such as yellow fever and Venezuelan equine encephalitis viruses in Central and South America, an many other arboviruses in the Amazon region of Brazil and in Trinidad, as well as Bancroftan filariasis in Southern Brazil has been long recognized (Arnel1 ${ }^{1}, 1976$; Lhuillier et. al..$^{24}$, 1981).

During 1975-1976 epidemics of human encephalitis occurred in Southern S. Paulo Sta- te, Brazil, reaching some coastal areas and the "Ribeira" Valley region. A virus recovered from human cases was recognized as an etiological agent and named Rocio virus (Lopes et al. ${ }^{26}$, 1978). Evidence indicated that mosquitoes were involved in its transmission, and because of the abundance of Ae. scapularis together with its feeding habits and behaviour associated with man in epidemic areas, this species was considered a potential vector (Forattini et $a 1.9,10,11,1978,1981)$, Its vector competence for Rocio virus transmission has been demonstrated under experimental conditions, even showing a degree of variation in "per os" infection rates (Mitchell and Forattini ${ }^{28}$, 1984; Mitchell et. al. $\left.{ }^{30}, 1986\right)$. Among several hypothesis that might explain these variations, in susceptibility are those that relate the occurrence of populations with different behaviour patterns.

* Partially supported by Grants n. B/76/80/238/00/99 ("Financiadora de Estudos e Projetos" FINEP) and n. 82/0286-1 ("Fundação de Amparo à Pesquisa do Estado de São Paulo" - FAPESP).

* Department of Epidemiology of the "Faculdade de Saúde Pública da Universidade de São Paulo" - Av. Dr. Arnaldo, 715 - 01255 - São Paulo, SP — Brazil. 
Mosquitoes of the genus Haemagogus play a leading role in the transmission of sylvan yellow fever in the Neotropical region. After demonstrations that these mosquitoes are capable of transmiting this virus by biting, various species of this genus were found naturally infected in South America (Whitman ${ }^{39}$, 1951; Pinheiro et al. ${ }^{36}, 1981$ ). In addition to yellow fever virus and certain other arboviruses, Mayaro virus has been isolated from naturally infected mosquitoes in an epidemic region (Hoch et $\mathrm{al}^{21}, 1981$ ). Southern Brazil is included in the distributional area of $\mathrm{Hg}$. capricornii and $\mathrm{Hg}$. leucocelaenus, which are considered potential vectors of forest yellow fever. Although the epidemiological patterns is characteristic of jungle environments, riverine gallery forests may provide the bridge for epizootic propagation along their course to other areas. Moreover, patches of residual forests in modified environments can provide shelters for Haemagogus and non-human primates that may be involved in the maintenance of the virus cycle. From such areas these mosquitoes may invade plantations or villages close to the forest, and even enter houses (Brès $\left.{ }^{2}, 1986\right)$. Another question deserving attention is the reinvasion of South America by Ae. aegypti and the threat of the resurgence of urban and rural yellow fever $\left(\mathrm{Groot}^{19}, 1980\right.$; $\left.\operatorname{Lima}^{25}, 1985\right)$. These considerations need to be studied in regions modified for agricultural purposes so as to clarify possible risks to human populations.

For these reasons a programme was initiated to investigate mosquitoes biting habits with regard to man in several environmental situations in Southern Brazil. Studies on daily activities and seasonal variations were focused on areas of S. Paulo State territory in the higland region. Results obtained for $A e$. scapularis were compared with data from the "Ribeira" Valley, a lowland region near the Atlantic coast, which was the site of previous studies (Forattini et al. ${ }^{11}, 1981$ ). The present paper reports results relating to Ae. scapularis and to two Haemagogus species, obtained from that programme.

\section{MATERIALS AND METHODS}

\section{The Study Areas}

All areas chosen for these studies are sites modified for agricultural purposes. Residual patches of forest and riverine gallery forests are characteristic landscap features of these areas. The studies were performed in the three following places:

\section{1. "Jacaré-Pepira" Valley in "Dourado" County}

2. "Lupo" Farm in "Araraquara" County

3. "Santa Helena" Farm in the County of "São João da Boa Vista"

The "Jacaré-Pepira" Valley area is essentially represented by a gallery of secondary woodland along the river margin, surrounded by extensive pasture lands. Its characteristics have already been described (Forattini ${ }^{8}, 1987$ ). The latitude of the three localities corresponds to nearly $22^{\circ} \mathrm{S}$ and the longitudes vary between $46^{\circ}$ and $49^{\circ} \mathrm{W}$ (Figure 1). The mean altitude is of $400-500 \mathrm{~m}$ in "Dourado", $500-600 \mathrm{~m}$ in "Araraquara" and 600-800m in "São João da Boa Vista". In the "Ribeira" Valley the altitude is $0-180 \mathrm{~m}$ above sea level. The macroclimate has a rainfall pattern that includes, as a general rhythm, two seasons consisting of a rainy warm one from October to March with an average annual rainfall of $1,000-1,100 \mathrm{~mm}$, and a drier and cooler one from April to September with $200-300 \mathrm{~mm}$ of rainfall (Departamento de Águas e Energia Elétrica ${ }^{5}, 1972$ ).

"Lupo" Farm is situated in the neighbourhood of "Araraquara" city, nearly $4 \mathrm{~km}$ from the urban boundary. The collection site was a patch of residual forest surrounded by extensive open fruit and sugar-cane plantations and pasture lands. "Santa Helena" Farm is situated $12 \mathrm{~km}$ south of the city of "São João da Boa Vista" and the collection site was located in a preserved residual forest patch, situated in the middle of extensive plantations and near human settlement. On "Lupo" Farm the ground topography is flatter than on "Santa Helena" Farm where uneven land predominates.

\section{Mosquito Sampling}

The mosquitoes were collected by means of 25-hour human bait catches. The methodology used in the collections and in the calculation of Williams' means ${ }^{-}\left(\overline{\mathrm{X}}_{\mathrm{W}}\right)$ and Nielsen "crep" unit intervals for the crepuscular periods, have already been fully described (Haddow $^{20}$, 1954; Nielsen ${ }^{32}$, 1961; Forattini et al. $\left.{ }^{11}, 1981\right)$.

Annual and monthly rainfall data were obtained from official records of the $S$. Paulo State civil service ("Fundação SEADE"14,15,16, 1981-1983 year books) or directly from 'Secretaria de Obras e Meio Ambiente" (S. Paulo State) ${ }^{*}$. These data are routinely recorded by 
several meteorological stations and for the purposes of this research, the following two were selected (Figure 1):

1. "Bariri" Station (2206'S; $48^{\circ} 45^{\prime} \mathrm{W} ; 445 \mathrm{~m}$ altitude) for the "Jacare-Pepira" and the "Lupo" Farm observations.
2. "Campininha" Station $\left(22^{\circ} 18^{\prime} S ; 47^{\circ}\right.$ 11 'W; $600 \mathrm{~m}$ altitude) for the "Santa Helena" Farm observations.

These choices were based on proimity to the study areas and their respective biogeographical similarity.

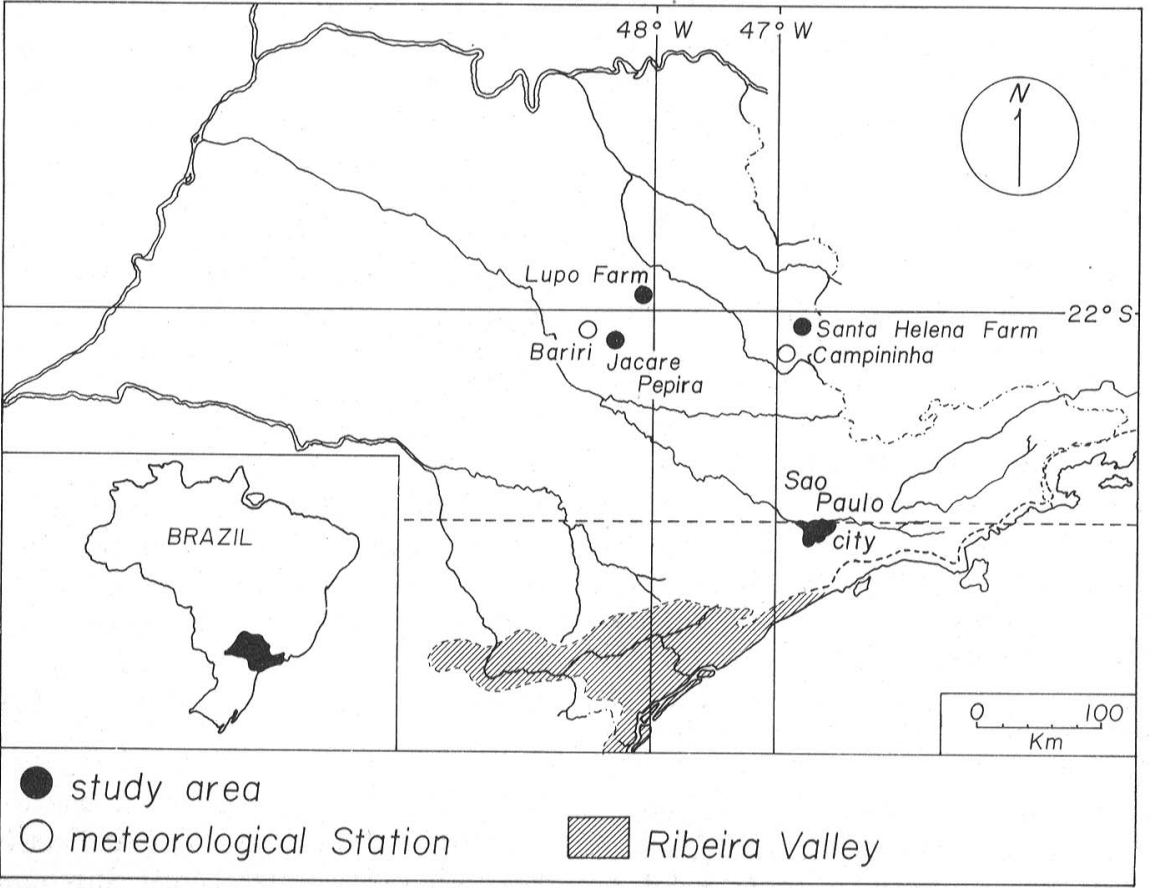

Fig. 1 - Map of S. Paulo State, Brazil, showing the study areas on the highland plateau and in the "Ribeira" Valley lowland region. Dotted line represente the eastern border of the plateau.

In the "Jacaré-Pepira" area human bait catches were made twice a month, once each alternate week, from March 1980 to April 1982. In the areas of "Lupo" and "Santa Helena" Farms collections were carried out monthly from April 1981 to April 1983, always in the same previously chosen week of the month.

\section{Mosquitoes Collected}

\section{RESULTS}

A total of 4,383 mosquitoes were caught with human bait, distributed according to the study areas as presented in Table.

\section{Aedes Scapularis}

The only reliable data to compute the hourly activities of the 25-hour human bait catches were obtained in "Jacaré-Pepira" and on "Lupo" Farm. The results of the twice-monthly collections in the former area, and the
TABLE

Mosquitoes collected with 25-hour human bait in the study areas.

\begin{tabular}{lrrr}
\hline Species & $\begin{array}{c}\text { "Jacaré- } \\
\text { Pepira" }\end{array}$ & $\begin{array}{c}\text { "Lupo" } \\
\text { Farm }\end{array}$ & $\begin{array}{c}\text { "Santa } \\
\text { Helena" } \\
\text { Farm }\end{array}$ \\
\hline Ae. scapularis & 789 & 338 & 82 \\
Hg. capricornii & 2 & 225 & 588 \\
Hg. leucocelaenus & 2 & 977 & 1,390 \\
\hline
\end{tabular}

monthly ones in the latter, are shown in Figure 2 , together with previously published data from the "Ribeira" Valley region. The $\mathbf{5 2}$ collections carried out in "Jacaré-Pepira" and the 25 on "Lupo" Farm, showed a distinct increase in crepuscular activity corresponding to sunset, and a much smaller, not so obvious one, at dawn. This pattern of biting activity was similar for all the three areas (Figure 2).

* 1983 data. Unpublished report. 


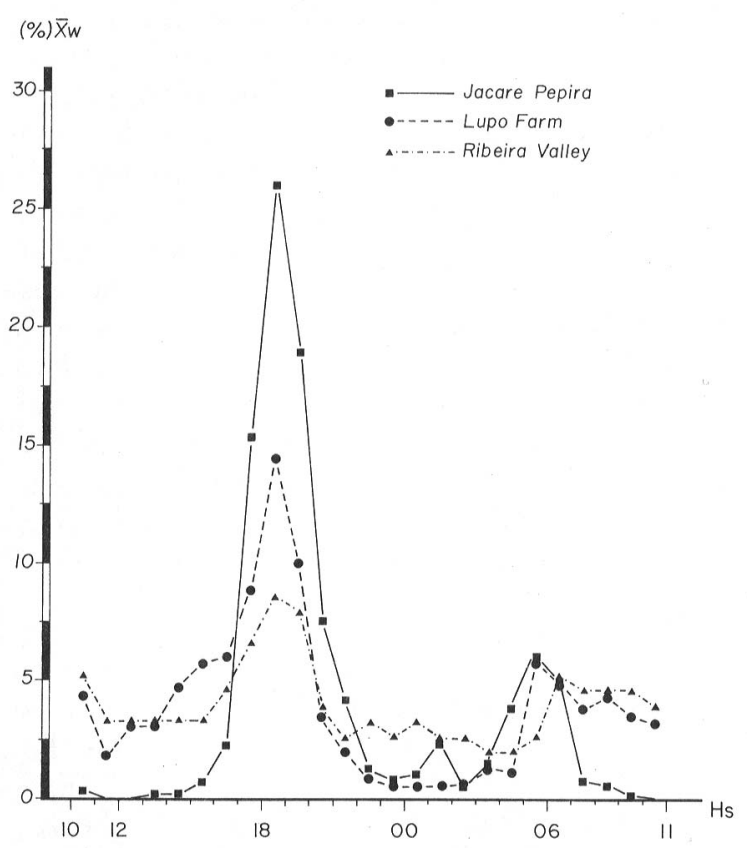

Fig. 2 . Hourly activity of Aedes scapularis caught at human bait, during regular catches in the "Jacaré-Pepira" and "Lupo" Farm areas, compared with the data formerly obtained in the "Ribeira" Valley region.

(\%) $\overline{\mathrm{X}}_{\mathrm{W}}-$ Williams' means percentage of the total obtained.

Hs - hours
Crepuscular and pericrepuscular activity, as exhibited at human bait around sunset has been plotted against "crep" units in Figure 3. This activity corresponds to collections in "Jacaré-Pepira" and on "Lupo" Farm during the period from 17.00-20.00 hours, and show that peak biting occurred during and around the vespertine crepuscular period (0.0-1.0 "crep" intervals). By comparing the three graphs it is possible to distinguish a precrepuscular peak obtained at "Lupo" Farm, and rather similar endocrepuscular peaks followed by clear posterior eocrepuscular ones at "Jacaré-Pepira" and in the "Ribeira" Valley.

The greatest numbers of Ae. scapularis were caught, in human bait catches during the periods corresponding to the cold months, from June to August, and at the beginning of the hot season, from October to November ( $\mathrm{Fi}$ gure 4). This behaviour was similar to that previously observed in the "Ribeira" Valley (Forattini et al. ${ }^{11}, 1981$ ) and seems to be associated with the period immediately prior to an increase in rainfall.

\section{Haemagogus species}

Available data concerns catches of Haemagogus capricornii and $\mathrm{Hg}$. leucocelaenus at the

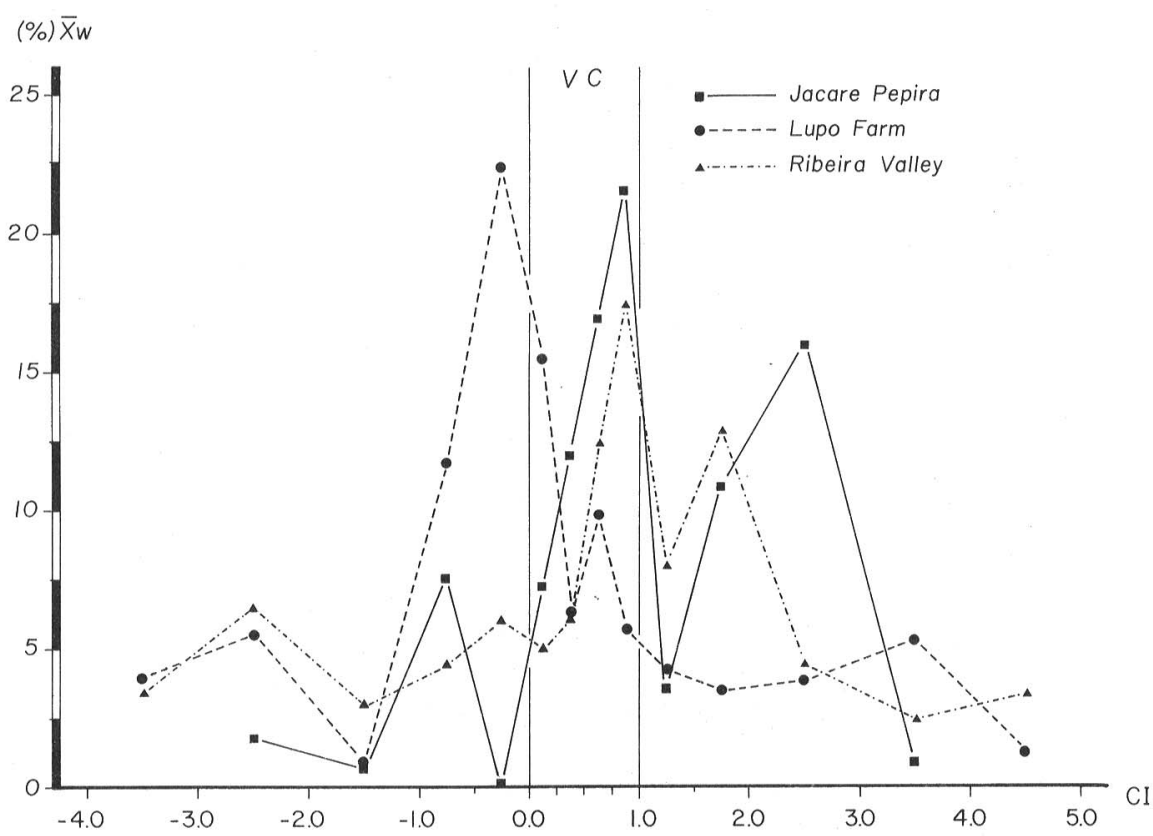

Fig. 3 - Vespertine crepuscular and pericrepuscular activities of Aedes scapularis with human bait in "Jacaré-Pepira" and on "Lupo" Farm, compared with the data formerly obtained in the "Ribeira" Valley region.

(\%) $\overline{\mathrm{X}}_{\mathrm{W}}$ - Williams' means percentage of the total obtained.

CI - Nielsen "crep" intervals, corresponding to $5.00-8.00 \mathrm{pm}$.

VC - Vespertine crepuscular period. 
(\%) $\bar{X} w$

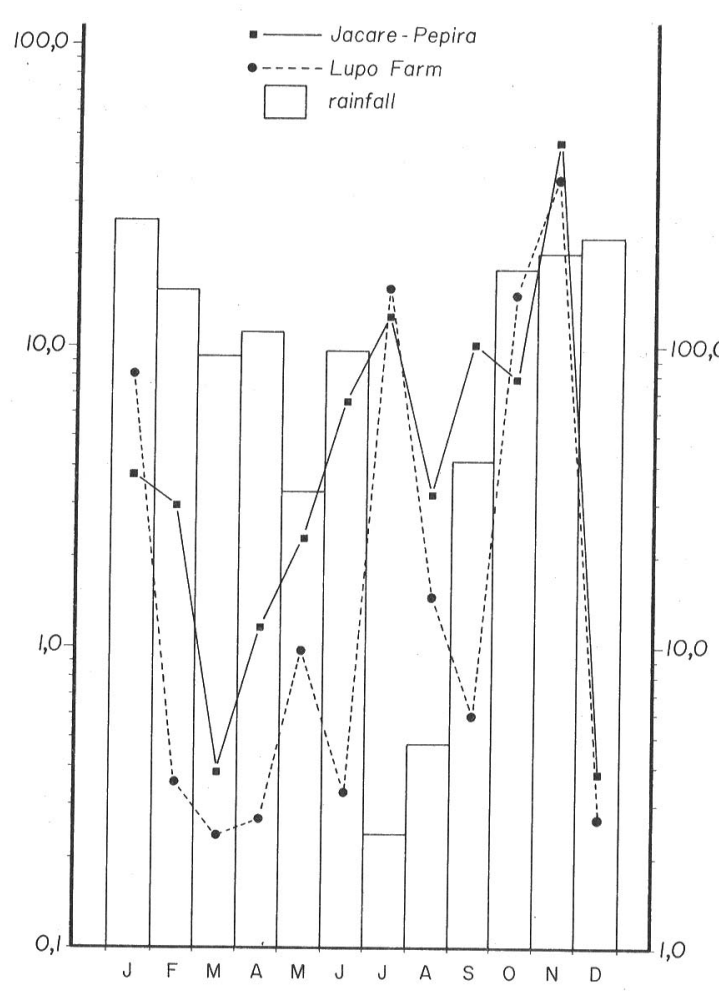

Fig. 4 - Seasonal incidence of Aedes scapularis at human bait in the "Jacaré-Pepira" and "Lupo" Farm areas, compared to rainfall. $(\%) \overline{\mathrm{X}}_{\mathrm{W}}$ - Williams' means percentage of the total obtained.

$\mathrm{mm}$ - monthly rainfall means in $\mathrm{mm}$. $\mathrm{M}$ - months

"Lupo" and "Santa Helena" Farms; and monthly 25-hour human bait collections provide the results presented in Figure 5. Clear diurnal activities were recorded for both species, with peaks around midday, that ar at 11.00 12.00 hours at "Santa Helena" Farm, and other peaks in the afternoon, between 14.0016.00 hours on "Lupo" Farm.

Studies on seasonal incidence showed greatest activity of both Haemagogus species during the rainy and hot months, with peaks coinciding with the October-January period as shown in Figure 6 at "Lupo" and "Santa Helena" Farms. No remarkable differences were observed between the two mosquito species.

\section{DISCUSSION}

There has been little previous research on the daily activity petterns of Ae. scapularis. Observations formerly made in Southern Brazil showed diurnal and nocturnal activity with a significant increase during the sunset period (Forattini $\left.{ }^{\top}, 1965\right)$. This pattern was afterwards confirmed for the same Brazilian region (Forattini et al. ${ }^{11}, 1981$; Oliveira and Silva ${ }^{35}, 1985$; Guimarães e Victório $\left.{ }^{18}, 1986\right)$. However, in Northern South America, at least in Surinam and French Guyenne, this mosquito was observed as being mainly diurnal with increased activity during the afternoon, between 12.00 hours and 15.00 or 16.00 hours, with no vespertine crepuscular peaks or nightly activity (Kruijf ${ }^{22}$, 1972; Degallier et al. $^{4}, 1978$ ). These two dissimilar behavioural patterns may suggest the presence of distinct populations or even species, and so more detailed studies in several biogeographical areas, as here in Southern Brazil, would seem to be appropriate.

During the present observations the biting activity of Ae. scapularis generally confirmed the above-mentioned pattern. Results obtained in the highland region, as compared with those formerly observed in the lowland "Ribeira" Valley (Forattini et al. ${ }^{11}, 1981$ ), showed broadly similar diel and seasonal activity patterns. Nevertheless, considering the crepuscular period around sunset, it was possible to identify endocrepuscular and pericrepuscular peaks (Figure 3). Catches in "Jacaré-Pepira" showed great similarity to those observed in the "Ribeira" Valley in that a clear endocrepuscular peak occurred, followed by another, upsurge in activity giving a postcrepuscular or eocrepuscular peak. In contrast the "Lupo" Farm population exhibited different behaviour, showing a well-marked precrepuscular peak without any other evident later peak. Since Ae. scapularis is usually considered to be a diurnal mosquito, the action of some exogenous stimulatory factor occurring during the vespertine period, such as light and/or microclimatic conditions, or even some endogenous factor, probably accounts for its observed patterns. Obviously both will modify the pattern of the observed diel biting cycles, and so it seems pertinent to raise the question of the existence of different populations at "Lupo" Farm, "Jacaré-Pepira" and the "Ribeira" Valley, which have different behaviours.

No other behavioural differences were observed between the three regions studied, for example, the seasonal incidences were quite similar, with increased activity soon after the start of the rains followed by a rapid decline in numbers, even in the hot rainy season (Figure 4). Taking into account regional differences it is clear that the pattern of rainfall will likely be very variable, so generally the activity and density of Ae. scapularis will vary 


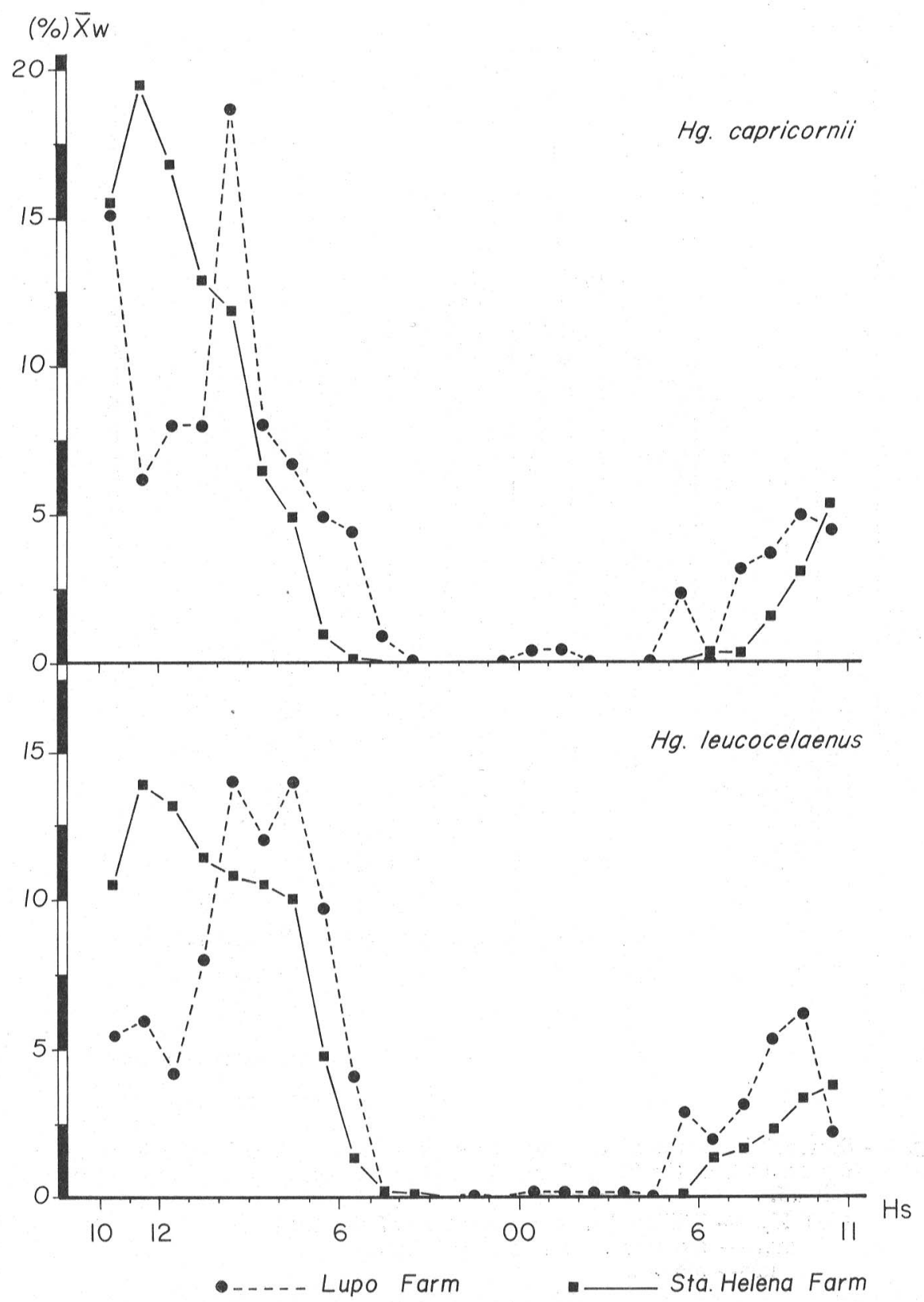

Fig. 5 - Hourly activity of Haemagogus capricornii and $\mathrm{Hg}$. leucocelaenus at human bait during regular catches in the "Lupo" and "Sta. Helena" Farms areas.

(\%) $\overline{\mathbf{X}}_{\mathrm{W}}-$ Williams' means percentage on the total obtained.

Hs - hours.

from place to place depending on the type of rainy season (Causey and Santos ${ }^{3}, 1949$; Kruijf 22, 1972; Guimarães and Arle ${ }^{17}, 1984$; Oliveira et $\left.\mathrm{al}^{34}, 1985\right)$. Nevertheless, the influence of rainfall on the density of $\mathrm{Ae}$. scapularis will be variable because it has drought-resistant eggs, and utilizes ground-pools as breeding places. Analysing catches in relation to rainfall distribution in the Brazilian Amazon region showed that the population den- sity of Ae. scapularis is not only governed by the preceeding amount of rainfall, but by alternating wet and dry periods (Kruijf et al..$^{23}$, 1973). These wet and dry periods are more commonly recorded in Southern than Northern Brazil, mainly in the so-called dry season, and this may explain to some extent the increased activity of Ae. scapularis at that time (Forattini et al. ${ }^{11}$, 1981). 


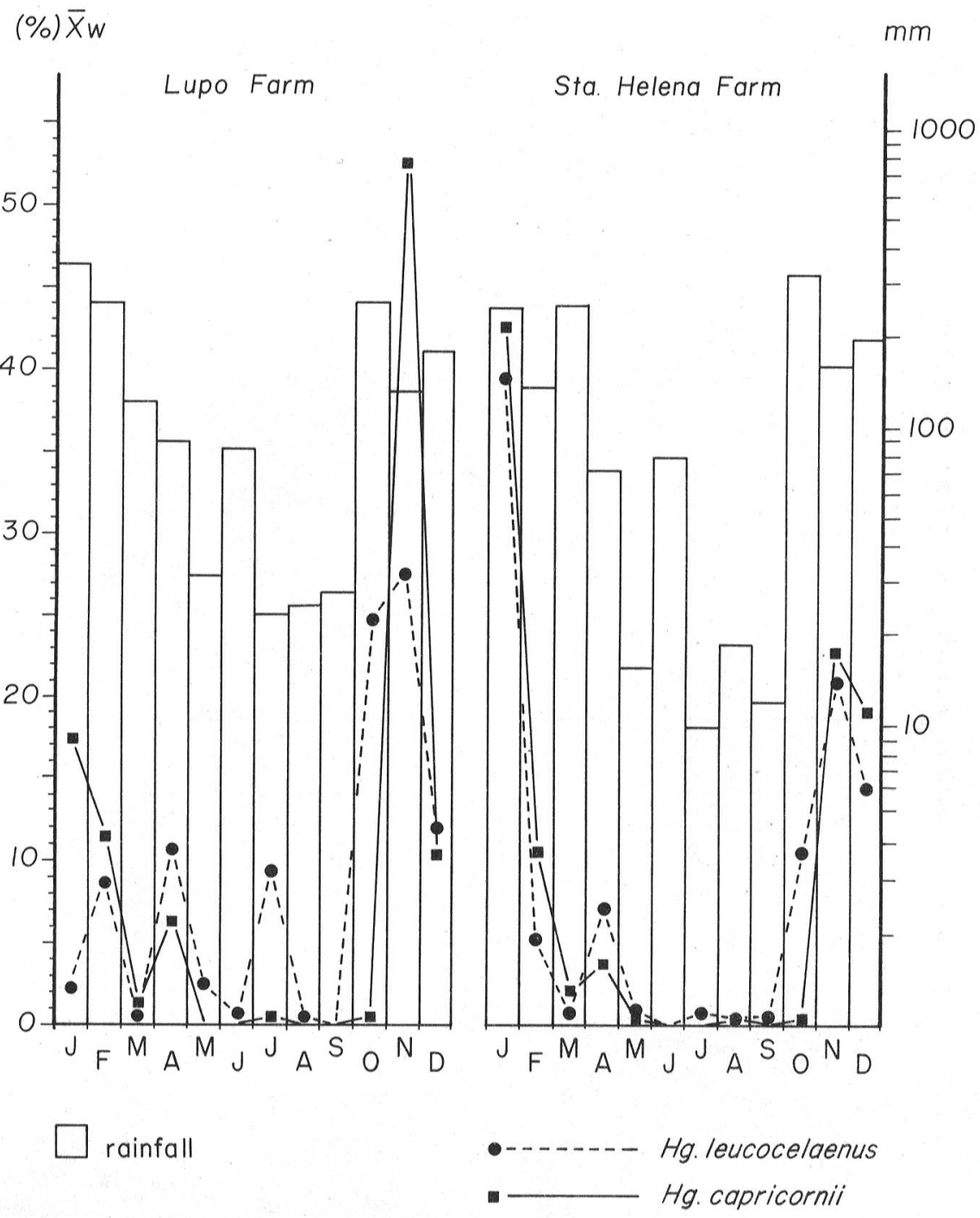

Fig. 6 - Seasonal incidence of Haemagogus capricornii and Hg. leucocelaenus at human bait, in the "Lupo" and "Sta. Helena" Farms areas, compared to rainfall.

(\%) $\bar{X}_{\mathrm{W}}$ - Williams' means percentage of the total obtained. $\mathrm{mm}$ - monthly rainfall means in $\mathrm{mm}$. $\mathrm{m}$ - months.

These observations confirm the clear characteristics of the activity and density of $A e$. scapularis in modified environments resulting from human action. "Jacaré-Pepira" and "Lupo" Farm represent areas more highly modified than the "Santa Helena" Farm, where residual forest has been better preserved and the mosquito density is very low. So these results agree with those formerly obtained in the "Ribeira" Valley, and support the hypothesis that the species has a high degree of adaptability to man-made environments (Forattini et $\left.a .^{11,12}, 1981,1986\right)$. Such adaptability seems to be widespread in South America, showing a clear tendency to endophily and to domiciliarity on the part of this species (Forattini et al. $.^{10,13}, 1978,1987$; Roberts et al..$^{37,38}$, 1981, 1985; Oliveira $\left.{ }^{33}, 1984\right)$. The epidemiological significance of this behaviour warrants further study, especially as recent observations in Northern Argentina suggest that Ae. scapularis may be involved in a chain of secondary transmission of the Venezuelan equine encephalitis virus (Mitchell et al. ${ }^{29}, 1985$ ).

With regard to both Haemagogus species, the available data obtained at "Lupo" and "Santa Helena" agree with those obtained in the residual or primitive forests of other Brazilian and South American regions. Hourly 
and seasonal incidence of activity shows a very constant and widespread pattern (Causey and Santos ${ }^{3}$, 1949; Kruijf ${ }^{22}$, 1972; Neves and Silva $^{31}$, 1973; Pinheiro et al. ${ }^{36}, 1981$; Guimarães and Arlé 17 $^{17} 1984$; Guimarães and Victório $\left.^{18}, 1986\right)$. However, small variation was observed in the biting cycles between the two study areas, in that peak activity as earlier on "Santa Helena" Farm, corresponding to midday, and later at "Lupo" Farm where it occurred during the early afternoon (Figure 5). It seems likely that these differences are related to distinct local features involving climatic and other aspects peculiar to the residual forests. At "Lupo" Farm the woods are mode modified that on "Santa Helena" Farm, and it is reasonable to suppose that more forested conditions at "Santa Helena" enhances more primitive behavioural aspects, such as the earlier peak biting activity at noon for these mosquitoes. No differences relating to their seasonal incidence, which is directly associated to rainfall were, found (Figure 6).

Both $\mathrm{Hg}$. capricornii and $\mathrm{Hg}$. leucocelaenus are known to be potential arbovirus vectors and on several occasions adults were obser- ved invading open areas with plantations, and even villages or houses close to the forest ( $\mathrm{Pi}$ nheiro et al. $^{36}, 1981$; Méndez et al. ${ }^{27}, 1984$ ). This behaviour must be considered together with the possibility of viruses penetrating into these residual forests by means of the migration of vertebrate reservoirs, which may result in virus transmission to man when he enters that environment or lives close to it. Besides this, it must be remembered that the reinvasion of Brazilian territory by Ae. aegypti may provide favourable conditions for the propagation of the yellow fever virus from these rural environments to the urban one. A good example of this possibility is represented by the situation at "Lupo" Farm where Haemagogus mosquitoes are common, and the farm is only about $4 \mathrm{~km}$ from "Araraquara" city where the urban yellow fever mosquito. Ae. aegypti, was recently found, that is since June $1986^{\circ}$.

\section{ACKNOWLEDGEMENT}

Prof. Dr. Jair Lício Ferreira Santos for his valuable help in the computer programming and statistical calculations on the data.

FORATTINI, O. P. \& GOMES, A. de C. Atividade hematófaga de mosquitos Aedes scapularis (Rondani) e Haemagogus no sul do Brasil (Diptera: Culicidae). Rev. Saúde públ., S. Paulo, 22:84-93, 1988.

RESUMO: No período de março de 1980 a abril de 1983 foi estudada a atividade hematófaga de uma população de Aedes scapularis (Rondani), Haemagogus capricornii Lutz, Hg. leucocelaenus (Dyar e Shannon), na região sul do Brasil. Os dados foram obtidos com o emprego de isca humana, mediante captura de 25 horas de duração e correspondente a três áreas, contendo manchas de floresta residual, denominadas Jacaré-Pepira, Fazenda Lupo e Fazenda Santa Helena. Os resultados relativos a Ae. scapularis foram comparados com as coletas anteriormente feitas em áreas de planície da região do Vale do Ribeira e que revelaram comportamento semelhante, exceto na Fazenda Lupo, onde foi observado um pico pré-crepuscular que não foi registrado em Jacaré-Pepira ou no Vale do Ribeira. Em todas as áreas aquele mosquito demonstrou atividade diurna e noturna. Essas observações alicerçam a hipótese sobre a capacidade de adaptação de Ae. scapularis em ambiente alterado pelo homem e as implicações epidemiológicas daí decorrentes. Quanto a Haemagogus, os dados obtidos nas Fazendas Lupo e Santa Helena concordam com os primeiros resultados obtidos em diversas outras regiões, nas quais se revela o caráter diurno de sua atividade. Nas proximidades da Fazenda Lupo, onde $\mathrm{Hg}$. capricornii e $\mathrm{Hg}$. leucocelaenus mostraram considerável atividade, está a cidade de Araraquara, onde o Ae. aegypti foi recentemente encontrado, e assim cabem consideraçōes epidemiológicas, sobre a possibilidade de ocorrência de febre amarela urbana.

UNITERMOS: Aedes scapularis. Haemagogus capricomii. Haemagogus leucocelaenus. Insetos vetores. Hematofagia. Ecologia de vetores. Infecções por arbovirus, transmissão. 


\section{REFERENCES}

1. ARNELL, J. H. |Mosquito studies (Diptera, Culicidae). XXXIII - A revision of the Scapularis Group of Aedes (Ochlerotatus). Contr. Amer. Ent. Inst., 13:1-144, 1976.

2. BRES, P. L. J. A century of progress in combating yellow fever. Bull. Wld Hlth Org., 64: 775-86, 1986.

3. CAUSEY, O. R. \& SANTOS, G. V. dos. Diurnal mosquitoes in an area of small residual forests in Brazil. Ann. ent. Soc. Amer, 42: 471-82, 1949.

4. DEGALLIER, N.;PAJOT, F. X.; KRAMER, R.; CLAUSTRE, J.; BELLONY, S.; LePONT, F. Rythmes d'activité des Culicidés de la Guyane française (Diptera, Culicidae). Cah. ORSTOM, Sér. Ent. méd. parasit., 16:73-84, 1978.

5. DEPARTAMENTO DE ĀGUAS E ENERGIA ELETRICA. Atlas pluviométrico do Estado de São Paulo: período 1941-1970. São Paulo, 1972.

6. FORATTINI, O. P. Some data on the domesticity of Aedes scapularis (Rondani) in São Paulo, Brazil. Mosquito News, 21:295-6, 1961.

7. FORATTINI, O. P. Entomologia médica. São Paulo, Ed. USP, 1965. v. 2.

8. FORATTINI, O. P. Exophilic behavior of Anopheles darlingi Root in southern region of Brazil. Rev. Saúde públ., S. Paulo, 21: 291-304, 1987.

9. FORATTINI, O. P.; GOMES, A. de C.; GALATI, E. A. B.; RABELLO, E. X.; IVERSSON, L. B. Estudos ecológicos sobre mosquitos Culicidae no sistema da Serra do Mar, Brasil. 1 - Observações no ambiente extradomiciliar. Rev. Saúde públ., S. Paulo, 12:297-325, 1978.

10. FORATTINI, O. P.; GOMES, A. de C.; GALATI, E. A. B.; RABELLO, E. X.; IVERSSON, L. B. Estudos ecológicos sobre mosquitos Culicidae no sistema da Serra do Mar, Brasil. 2 - Observações no ambiente domiciliar. Rev. Saúde públ., S. Paulo, 12:476-96, 1978

11. FORATTINI, O. P.; GOMES, A. de C.; SANTOS, J. L. F.; GALATI, E. A. B.; RABELLO, E. X.; NATAL, D. Observações sobre atividade de mosquitos Culicidae, em mata residual no Vale do Ribeira, São Paulo, Brasil. Rev. Saúde públ., S. Paulo, 15:557-86, 1981.

12. FORATTINI, O. P.; GOMES, A. de C.; NATAL, D.; SANTOS, J, L. F. Observações sobre atividade de mosquitos Culicidae em matas primitivas da planície e perfís epidemiológicos de vários ambientes no Vale do Ribeira, São Paulo, Brasil. Rev. Saúde públ., S. Paulo, 20:178-203, 1986.

13. FORATTINI, O. P.; GOMES, A. de C.; NATAL, D.; KAKITANI, I.; MARUCCI, D. Frequência domiciliar e endofilia de mosquitos Culicidae no Vale do Ribeira, São Páulo,
Brasil. Rev. Saúde públ., S. Paulo, 21:188-92, 1987.

14. FUNDAÇÃO SEADE. Anuário estatístico do Estado de São Paulo, 1981. São Paulo, 1982.

15. FUNDAÇÃO SEADE. Anuário estatístico do Estado de São Paulo, 1982. São Paulo, 1983.

16. FUNDAÇÃO SEADE. Anuario estatístico do Estado de São Paulo, 1983. São Paulo, 1984.

17. GUIMARÃES, A. E. \& ARLE, M. Mosquitos no Parque Nacional da Serra dos Orgãos, Estado do Rio de Janeiro, Brasil. I - Distribuição estacional. Mem. Inst. Oswaldo Cruz, Rio de Janeiro, 79:309-23, 1984.

18. GUIMARÃES, A. E. \& VICTÓRIO, V. M. N. Mosquitos no Parque Nacional da Serra dos Órgãos, Estado do Rio de Janeiro, Brasil. III - Preferência horária para hematofagia. Mem. Inst. Oswaldo Cruz, Rio de Janeiro, 81:93-103, 1986.

19. GROOT, H. The reinvasion of Colombia by Aedes aegypti: aspects to remember. Amer. J. trop. Med. Hyg., 29:330-8, 1980.

20. HADDOW, A. J. Studies on the biting-habits of African mosquitoes: an appraisal of method employed, with special reference to the twenty-four-hour catch. Bull. ent. Res., 45:199-242, 1954.

21. HOCH, A. L.; PETERSON, N. E.; LeDUC, J. W.; PINHEIRO, F. P. An outbreak of Mayaro virus disease in Belterra, Brazil. III Entomological and ecological studies. Amer. J. trop. Med. Hyg., 30:689-98, 1981.

22. KRUIJF, H. A. M. de Aspects of the ecology of mosquitoes in Surinam. Stud. Fauna Suriname other Guyanas, 13:3-56, 1972.

23. KRUIJF, H. A. M. de; WOODALL, J. P.; TANG, A. T. The influence of accumulated rainfall and its pattern on mosquito (Diptera) populations in Brazil. Bull. ent. Res., 63: $327-33,1973$.

24. LHUILLIER, M.; PAJOT, F. X.; MOUCHET, J.; ROBIN, Y. Arboviroses en Amerique du Sud e dans les Caraibes. Méd. trop., 41:73-84, 1981.

25. LIMA, J. T. F. Risco de urbanização da febre amarela no Brasil. Cad. Saúde públ., 1:377-85, 1985.

26. LOPES, O. de; COIMBRA, T. L. M.; SACCHETTA, L. de A.; CALISHER, C. H. Emergence of a new arbovirus disease in Brazil. I - Isolation and characterization of the etiologic agent, Rocio virus. Amer J. Epidem., 107:444-9, 1978.

27. MENDEZ, M. R.; CALISHER, C. H.; KRUGER, H.; SIPAN, F.; SANCHEZ, S.; LAZUICK, J. S. Foco permanente de fiebre amarilla en el Valle del rio Apurimac, Ayacucho, Peru, y primer aislamiento del virus de la fiebre amarilla en ese pais. Bol. Ofic. sanit. panamer., 97:215-24, 1984. 
28. MITCHELL, C. J. \& FORATTINI, O. P. EXperimental transmission of Rocio encephalitis virus by Aedes scapularis (Diptera: Culicidae) from the epidemic zone in Brazil. $J$. med. Ent., 21:34-7, 1984.

29. MITCHELL, C. J.; MONATH, T. P.; SABATTINI, M. S.; CROPP, C. B.; DAFFNER, J. F.; CALISHER, C. H.; JAKOB, W. L.; CHRISTENSEN, H. A. Arbovirus investigation in Argentina, 1977-1980. II - Arthropod collections and virus isolations from Argentine mosquitoes. Amer. J. trop. Med. Hyg., 34:945-55, 1985.

30. MITCHELI, C. J.; FORATTINI, O. P.; MILLER, B. R. Vector competence experiments with Rocio virus and three mosquito species from the epidemic zone in Brazil. Rev. Saúde públ., S. Paulo, 20:171-7, 1986.

31. NEVES, D. P. \& SILVA, J. E. da. Aspectos da biologia dos culicinae do Parque das Mangabeiras, Belo Horizonte. I - Espécies locais e variação estacional. Arq. Esc. Vet., 25:287-98, 1973.

32. NIELSEN, E. T. Twilight and the "crep" unit. Nature, 190:878-9, 1961.

33. OLIVEIRA, R. L. de. Alguns aspectos da ecologia de mosquitos (Diptera: Culicidae) em uma área de planície (Granjas Calábria), em Jacarepaguá, Rio de Janeiro. I - Freqüência comparativa das espécies em diferentes ambientes e métodos de coleta. Mem. Inst. Oswaldo Cruz, Rio de Janeiro, 79:479-90, 1984.

34. OLIVEIRA, R. L. de; SILVA, T. F. da; HEYDEN, R. Alguns aspectos da ecologia dos mosquitos (Diptera: Culicidae) em uma área de planície (Granjas Calábria) em Jacarepaguá, Rio de Janeiro. II - Frequiência mensal e no ciclo lunar. Mem. Inst. Oswaldo Cruz, Rio de Janeiro, 80:123-33, 1985.

35. OLIVEIRA, R. L. de \& SILVA, T. F. Alguns aspectos da ecologia de mosquitos (Diptera: Culicidae) de uma área da planície (Granjas Calábria), em Jacarepaguá, Rio de Janeiro. III - Preferência horária das fêmeas para o hematofagismo. Mem. Inst. Oswaldo Cruz, Rio de Janeiro, 80:195-201, 1985.

36. PINHEIRO, F. P.; ROSA, A. P. T. da; MORAES, M. A. P. An epidemic of yellow fever in Central Brazil, 1972-1973. II - Ecological studies. Amer. J. trop. Med. Hyg., 30: 204-11, 1981.

37. ROBERTS, D. R.; HOCH, A. L.; PETERSON, N. E.; PINHEIRO, F. P. Programa multidisciplinario de vigilancia de las enfermedades infecciosas en zonas colindantes con la carretera transamazonica en Brasil. IV - Estudio entomologico. Bol. Ofic. sanit. panamer., 91: 379-400, 1981.

38. ROBERTS, D. R.; PEYTON, E. L.; PINHEIRO, F. P.; BALDERRAMA, F.; VARGAS, $\mathbf{R}$. Asociación de vectores de arbovirus con galerias arboreas y el medio domestico en el sureste de Bolivia. Bol. Ofic. sanit. panamer., 98:417-30, 1985.

39. WHITMAN, L. The arthropod vectors of yellow fever. In: Strode, G. K., ed. Yellow fever. New York, McGraw-Hill, 1951. p. 229-98.

Received for publication: 19/11/1987 Accepted for publication: 29/3/1988 